\title{
Exploring the South African tax consequences of a residential property lottery
}

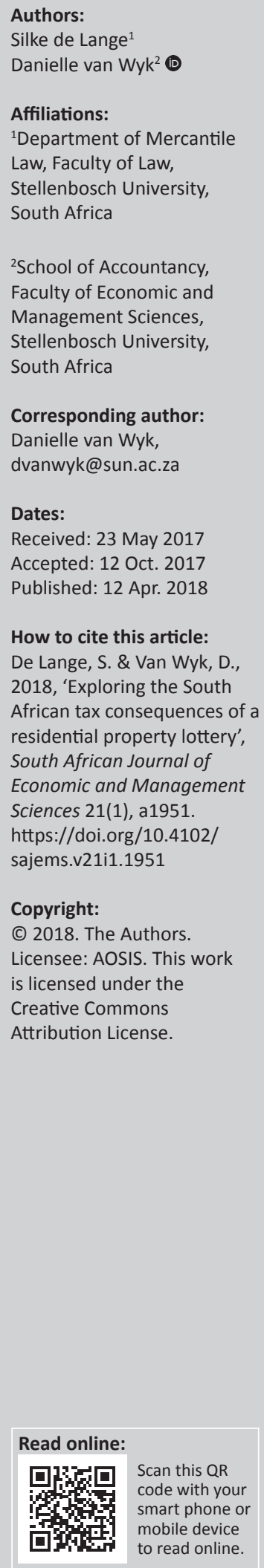

Background: Disposing of a residential property by way of a lottery sounds peculiar, but a number of these transactions relating to residential properties in South Africa have recently taken place. As this is not an ordinary way of disposing of and acquiring residential property, it is submitted that it is necessary to explore the tax consequences resulting from such a transaction.

Aim: The objective of this article is to explore some of the most pertinent South African tax consequences of such a residential property lottery transaction, from the viewpoint of the owner ('seller') who disposes of the residential property and the winner ('purchaser') who acquires the residential property in terms of the lottery.

Setting: This article examines existing literature in a South African income tax environment to explore the tax consequences resulting from a disposal and acquisition of residential property by way of a lottery.

Methods: A non-empirical study, which entails the study of the various South African tax provisions and an application thereof to the facts of the lottery transaction, was conducted. A doctrinal research approach was followed within the realm of exploratory research.

Results: Disposing of and acquiring residential property by way of a lottery results in a number of actual tax consequences, as well as a number of uncertainties regarding taxes (referred to as uncertain considerations).

Conclusion: The conclusion is reached that the possible tax consequences of such a transaction can create tax risks or can result in unintended tax consequences relating to inter alia income tax (including capital gains tax), transfer duty and donations tax. The insights provided in this article do not always result in conclusive answers but they may, however, result in further research to be conducted, and a number of such areas for further research were identified. Should residential property lottery transactions occur more frequently in South Africa in future, it is recommended that the South African Revenue Services (SARS) issues clear guidance on the tax treatment from the perspective of the owner and the winner of such a transaction to ensure that any uncertainties are dealt with correctly.

\section{Introduction}

Disposing of a residential property by way of a lottery sounds peculiar, but a number of these transactions relating to residential properties in South Africa have recently taken place. According to Tswanya (2015), one transfer of residential property situated in the Val de Vie Estate in Paarl and two transfers of residential properties situated in the Diemersfontein Estate between Wellington and Paarl took place in the form of a residential property lottery.

As such residential property lottery transactions are unconventional, especially in South Africa, no academic literature currently exists on the topic in South Africa. In the United Kingdom, for example, the Law Society issued a practice note titled 'House Competitions' in 2011 due to the increase of such transactions (United Kingdom Law Society 2011). It is stated in the practice note that this increase can be ascribed to factors such as an economic recession, which makes it more difficult for home-buyers to obtain financing and that home-owners are therefore trying to sell their properties by way of a competition in which the property can be won (United Kingdom Law Society 2011). The United Kingdom Law Society notes in the practice note that one of the risks associated with these transactions is the possibility of fraud by not paying the relevant taxes (United Kingdom Law Society 2011). It is submitted that similar risks associated with property lottery transactions exist in South Africa, but no similar guidance on such transactions and their consequences is currently available. 
The terms and conditions of the lottery of the house situated in Val de Vie ('the Property') were evaluated for purposes of this article. As the Property is situated in South Africa, the objective of this article is to explore some of the most pertinent South African tax consequences of such a transaction from the viewpoint of the owner (the person in a position similar to a seller in a typical sale transaction) who disposes of the Property in terms of the lottery, and from the viewpoint of the winner (the person in a position similar to a buyer in a typical sale transaction) who acquires the Property in terms of the lottery.

To illustrate how the lottery works, the facts of the specific transaction relating to the Property, as noted by Tswanya (2015), and the lottery's terms and conditions are presented. The tax consequences discussed below are based on these facts: The lottery of the Property was administered in Austria by an Austrian attorney and 9999 lottery tickets or lots were available to be sold at $€ 119$ each. Payment for a lot had to be made into a trust account of the Austrian attorney. Once all the lots were sold, a draw took place and the winning lot won the Property, as well as a number of additional prizes, being the contents of the Property (such as furniture), two return flights to South Africa and accommodation for a week, including meals, tours and transport. A further promotional prize (a safari tour) was also available upon the condition that the winner agreed to have his or her name published, together with a photo and a follow-up story. The owner of the Property was only entitled to funds that equal the market value of the Property. The proceeds realised from the sale of the lots, however, far exceeded the market value of the Property. The proceeds realised from the sale of the lots, after deducting the market value that was paid over to the owner and after deducting costs, such as the costs of the transfer of the Property and the costs of the lottery, had to be paid over to a charity. Further specific terms and conditions relating to the lottery transaction will be referred to below, as those are relevant or applicable to a specific tax issue being explored.

In essence, the owner realises the full market value on the disposal of the Property but also obtains some additional benefits. It was stated by the owner that there are benefits from disposing of the Property in this way such as not being liable for estate agent commission (which is usually paid over by the owner to the estate agent from the sale price) (Tswanya 2015). Further, it was stated that selling the Property in this way has the benefits that the owner does not have to make the house available for viewings, that the owner does not have to consider any offers, and that the sale will not be subject to conditions such as the buyer's mortgage bond approval (Tswanya 2015).

The winner pays a fixed amount for the lot and, upon acceptance, acquires the Property with a substantially higher value in return together with some additional prizes and an optional promotional prize.

\section{Limitations and assumptions}

Focus is placed on exploring the tax consequences for both the owner and winner, and it is assumed that both are natural persons. It is, however, unknown whether the owner of the Property and the winner of the Property are 'residents' as defined for tax purposes. The tax consequences of a transaction often vary depending on the tax residency status ('resident' or 'non-resident') of the parties involved. The Income Tax Act 58 of 1962 ('the Income Tax Act') defines a resident as a natural person who is ordinarily resident in the Republic, or a natural person who is not at any time during the relevant year of assessment ordinarily resident in the Republic, if that person was physically present in the Republic for a prescribed number of days during the relevant year of assessment and the 5 years of assessment preceding that year of assessment (Section 1 of the Income Tax Act). It seems from the terms and conditions that the lottery was mainly aimed at selling lots to foreigners. This is clear from the facts as the additional prize includes air tickets to South Africa and because a participant in the lottery was required to be in possession of a valid passport and visa to travel to South Africa. However, 'participants from South Africa' also purchased lots (Tswanya 2015). The winner could thus either have been a 'resident' or a 'non-resident', and the same would apply to the owner. The discussion below however assumes that both the owner and the winner are 'residents' as defined.

It is further assumed that neither the owner nor the winner is a 'vendor' as defined in the Value-Added Tax Act 89 of 1991 and that the transaction therefore has no value-added tax consequences.

The scope of the article is limited to residential property only. Specific consequences, should such residential property constitute a person's primary residence, are addressed below. The provisions of the Income Tax Act relating to deductions for residential buildings, residential units and low-cost residential units (Sections 13ter, 13sex and 13sept) fall beyond the scope of this article. The article further focuses only on the tax consequences relating to the Property, and does not include a discussion on the tax consequences relating to the contents of the Property, the additional prizes and the promotional prize.

The legality or lawfulness of such a lottery in South Africa, or whether it is allowed for South African citizens to take part as owners or buyers of lots in such a lottery, falls beyond the scope of this article. It was reported that 'participants from South Africa are accounting for a good portion of the people taking part' (Tswanya 2015). For purposes of this article it will be assumed that a valid transaction was successfully concluded.

The terms and conditions of the lottery provide that the owner may decide to discontinue the lottery if participation is not sufficient, in which case the buyers of lots will be refunded. The discussion below is, however, based on the 
assumption that all the lots are sold and that the draw proceeds. It is further assumed that the proceeds from the sale of the lots will cover at least the market value of the Property, the costs of the additional prizes and promotional prize and all the other costs that are covered from the lottery takings and that an amount to be donated to a charity remains thereafter.

It is assumed that the charity to whom the donation is made is an approved public benefit organisation as contemplated in Section 30(3) of the Income Tax Act. It is not clear from the available terms and conditions who the donor of this donation to the charity is. It is, however, assumed that the donor is not the owner as the owner is only entitled to the market value of the property.

It should lastly be noted that all the tax aspects that are explored below could not be addressed comprehensively and in depth in this article. This creates opportunities for further research as referred to in the conclusion.

\section{Research method and design}

What are the most pertinent South African tax consequences of disposing of a residential property by way of a lottery for the owner and the winner? This is the research question this article aims to address, within the realm of exploratory research. The research objective of this article is to explore some of the most pertinent South African tax consequences of such a transaction as no such research currently exists and no specific guidance is available in this regard.

A non-empirical study, which entails the study of the various South African tax provisions and an application thereof to the facts of the lottery transaction, was conducted. Hutchinson and Duncan (2012) suggest the following steps to solve a specific research problem, referred to as a doctrinal research approach:

- gathering the relevant facts

- identifying the relevant tax issue at hand

- analysing the issue from a tax perspective

- studying relevant background material such as textbooks and journal articles, inter alia

- analysing primary research sources such as case law and legislation

- combining all issues within the context

- reaching a preliminary conclusion.

The doctrinal research approach is embedded within the ambit of exploratory research in this article. Exploratory research entails focusing on research problems that have not been previously investigated (Brown 2006:46) and does not intend to provide a conclusive answer to research problems, but it can provide significant insights on the matter (Singh 2007:64). While it is acknowledged that the insights provided in this article do not always provide conclusive answers, it may, however, result in further research to be conducted. Exploratory research is therefore considered to be appropriate to this study.
The research objective was achieved by doing the following:

- evaluating the facts of such a transaction as included in the terms and conditions of the lottery

- identifying the capital gains tax, other income tax, donations tax and transfer duty issues at hand

- analysing the relevant tax issues from the perspective of the owner and the winner

- studying and analysing available resources such as textbooks, case law and legislation to explore the South African tax consequences

- reaching a preliminary conclusion within the ambit of exploratory research.

Even though such property lottery transactions might not take place regularly, it is important to consider the tax consequences thereof as the benefits seem to be attractive upfront, although it might not necessarily be the case once the tax consequences are taken into account. This article should not be construed as tax advice on such a transaction, but should rather be seen as exploring some of the most pertinent tax consequences in order to establish tax risk areas or uncertainties, some of which could have been unforeseen, for both the owner and the winner involved in the transaction. The research is conducted in order to create an awareness of the most pertinent South African tax consequences of such a transaction, thereby creating opportunities for further research.

While some actual tax consequences are discussed, a number of possible but uncertain tax consequences are also highlighted in this article. These are referred to as tax considerations and are seen as areas of uncertainty with possible tax risks.

\section{Results and discussion of the South African tax consequences and considerations}

The tax consequences and considerations are discussed below in the following order. Firstly, the capital gains tax consequences for the owner are explored (considering the disposal of an asset by the owner on the transfer of the Property by way of the lottery), followed by the capital gains tax consequences for the winner. The capital gains tax consequences for the winner include a discussion of capital gains tax on gambling, games or competitions and a discussion of the base cost of the Property for purposes of a future disposal of the Property by the winner. Subsequently, other income tax considerations are explored for the owner and the winner respectively. For the owner, it is considered whether the fact that the owner decides to dispose of the Property by way of a lottery, instead of by way of an ordinary sale, could result in the owner moving over from the realisation of a capital asset to a scheme of profit-making. It is also considered whether the savings or advantages relating to the disposal of the Property by way of the lottery (compared to an ordinary sale) could result in any tax consequences in the hands of the owner. For the winner, it is considered 
whether any income tax consequences arise due to the difference between the amount paid for the lot and the value of the Property received in return as a prize. Transfer duty and donations tax are two other types of taxes which are explored thereafter.

\section{Capital gains tax consequences}

\section{Capital gains tax consequences for the owner}

For a capital gain or loss to possibly exist for the owner on the transfer of the Property by way of the lottery, paragraphs 2(a), 3 and 4 of the Eighth Schedule to the Income Tax Act require an asset, disposal, base cost and proceeds to be present. Immovable property is included as an 'asset' in paragraph 1 of the Eighth Schedule. In terms of paragraph 11(1)(a) of the Eighth Schedule, the sale, donation, exchange or any other alienation or transfer of ownership of an asset is considered to be a disposal for capital gains tax purposes. None of the disposal exclusions as listed in paragraph 11(2) of the Eighth Schedule are applicable to this specific transaction. Accordingly, the transfer of the ownership of the Property in terms of the lottery from the owner to the winner can be regarded as the disposal of an 'asset'. It is submitted that it falls beyond the scope of this article to determine the exact type of disposal (e.g. as a sale, donation or exchange) as it is in any event a 'transfer of ownership of an asset'.

To determine the base cost of the Property, it should be established whether the Property was acquired by the owner before or after 01 October 2001 ('valuation date' as per paragraph 1 of the Eighth Schedule). The first properties on Val de Vie (where the Property is situated) were only purchased in 2004 (Val de Vie 2016); therefore, the Property could only have been bought by the owner after 01 October 2001 and thus no valuation calculations are required in terms of the Eighth Schedule on 01 October 2001 to determine the base cost. Paragraph 20(1) of the Eighth Schedule provides that the base cost of an asset is the sum of, among others:

- the expenditure actually incurred in respect of the cost of acquisition or creation of that asset (this would include the cost price of the erf and the costs of the erection of the house by the owner)

- amounts actually incurred as expenditure directly related to the acquisition or disposal of that asset such as transfer costs, transfer duty and advertising costs (paragraphs 20(1)(a) and (c) of the Eighth Schedule).

The promotional and other costs relating to the disposal will be recovered from the balance between the market value of the Property and the total value of all lots sold (Tswanya 2015). These costs relating to the disposal of the Property by the owner could, in principle, be considered to form part of the base cost according to paragraph 20(1)(c) of the Eighth Schedule. However, seeing that such costs are recoverable from 'any other person' as referred to in paragraph 20(3)(b) of the Eighth Schedule, such costs are excluded from the base cost as these costs will be paid from the lottery takings exceeding the market value of the Property, and therefore will be recoverable, albeit indirectly, from the lottery participants.

Proceeds from the disposal are the final requirement to be determined. According to paragraph 35(1) of the Eighth Schedule, the proceeds from a disposal are equal to the amount received by or accrued to that person in respect of that disposal. In Geldenhuys v CIR (3) All SA 379 (C):389 it was held that 'received' means 'received by the taxpayer on his own behalf for his own benefit'. 'Accrued' on the other hand means 'to which the taxpayer has become entitled to' (Lategan WH v CIR 2 SATC 16:20).

In this specific transaction, the owner may recover the current market value of the Property, namely R5.7 million (Tswanya 2015). The value of the total 9999 lots sold at R1658 a lot (Tswanya 2015 based on $€ 119$ per lot, converted at an exchange rate of $€ 1: R 13.93)$, will however be approximately R16.5 million. The question is, therefore, which of these two amounts (the market value or the total value of the lots sold) will be seen as the proceeds for capital gains tax purposes. As the terms and conditions of the lottery provide that the owner is only entitled to the market value of the Property, the smaller amount of R5.7 million as the market value of the Property is submitted to be the proceeds for capital gains tax purposes, as the owner is only entitled to receive this amount for his or her own benefit. As mentioned above, it is assumed that the owner is only entitled to the market value of the Property.

Paragraph 38(1)(a) of the Eighth Schedule provides that the proceeds of an asset are equal to the market value of the asset for the person who disposed of the asset (i.e. for the owner) in certain circumstances. The application of paragraph 38 of the Eighth Schedule to the lottery is further considered below. Paragraph 38 of the Eighth Schedule would, however, not affect the determination of the proceeds for the owner in terms of paragraph 35 of the Eighth Schedule as it would in any event be the market value of the Property.

After determining the base cost and the proceeds of the Property, a capital gain or loss must be calculated on the disposal in terms of paragraphs 3 or 4 of the Eighth Schedule. If a capital gain or loss exists in this specific transaction, the application of paragraph 45(1) of the Eighth Schedule should also be considered. The owner as natural person will be allowed to disregard R2 million of the aggregate capital gain or loss determined with regard to the disposal in the case of the Property being a 'primary residence'. 'Primary residence' is defined in paragraph 44 of the Eighth Schedule as, essentially, a residence in which a natural person holds an interest and which that person or a spouse of that person ordinarily resides or resided in as his or her main residence and uses or used mainly for domestic purposes.

Therefore, if the Property in this specific transaction is the only primary residence of the owner and the requirements of paragraph 45 of the Eighth Schedule are met, the owner will 
be entitled to the primary residence exclusion. The owner will, however, not be entitled to the 'personal-use assets' exclusion in terms of paragraph 53(1) of the Eighth Schedule, due to 'immovable property' being excluded from 'personaluse assets' in terms of paragraph $53(3)(b)$ of the Eighth Schedule.

As the lottery lots were sold for $€ 119$, with participants from all over the world, including an Austrian lawyer and European promotor (Tswanya 2015), paragraph 43(1A) of the Eighth Schedule should also be considered. This paragraph relates to exchange rates where a person disposes of an asset for proceeds in a foreign currency or after having incurred expenditure in respect of that asset in a foreign currency. This will result in careful consideration and detailed attention when computing the owner's capital gain or loss on the disposal.

\section{Capital gains tax consequences for the winner}

Capital gains tax on gambling, games or competitions: If it is assumed that the winner did not take part in this lottery as a business or as part of a profit-making scheme, then the receipts will be capital in nature and therefore excluded from the winner's 'gross income' (Ostler 2013, and see also below for a more detailed discussion on capital nature and 'gross income'). The capital receipt in this regard (value of the Property) is significantly higher than the lot's price. Paragraph 60(1) of the Eighth Schedule applies to the winner of a gamble, game or competition when winning and provides that a person must disregard a capital gain or capital loss determined in respect of a disposal relating to any form of gambling, game or competition. The capital gain or loss, which is generally disregarded, would be calculated as the difference between the value of the prize and the cost of taking part in the gamble, game or competition. Paragraph $60(2)(b)$ of the Eighth Schedule, however, provides that a capital gain may not be disregarded by any natural person, unless that form of gambling, game or competition is authorised by, and conducted in terms of, the laws of the Republic. In essence, legal gambling, games or competitions in South Africa do not give rise to a capital gain or a capital loss for the winner upon winning, but winnings from illegal or foreign gambling, games or competitions are subject to capital gains tax if there is a capital gain.

The first question that arises is whether this lottery of the Property is considered to be 'any form of gambling, game or competition'. The SARS Comprehensive Guide to Capital Gains Tax ('CGT Guide') (2015:452) indicates that paragraph 60 of the Eighth Schedule 'encompasses all manner of activities such as horse racing, the National Lottery, casino winnings and the like'. If it is assumed that this lottery is a form of gambling, game or competition, the second question is whether it is a form of gambling, game or competition that is authorised by, and conducted in terms of, the laws of the Republic. In this case, the lottery is legal in Austria and is administered and legally takes place in Austria (Qukula 2015), but it is not clear whether the lottery is also authorised by, and conducted in terms of, the laws of the Republic. As stated earlier, the legality or lawfulness of such a lottery in South Africa or whether it is allowed for South African citizens to take part as owners or buyers of lots in such a lottery falls beyond the scope of this article. However, Kok (2009) points out that a similar raffle scenario could be considered as an illegal lottery in South Africa. Without concluding on this matter, it is submitted that the capital gain cannot be disregarded and that the winning of the Property will be subject to capital gains tax should paragraph $60(2)(b)$ of the Eighth Schedule be applicable. This will give rise to a substantial capital gain in the hands of the winner, determined as the difference between the value of the prize (R5.7 million as the value of the Property) and the cost of taking part in the gamble, game or competition (R1658 as the amount paid for a lot).

Base cost of the property: Irrespective of the application of paragraph 60 of the Eighth Schedule, the base cost of the Property for the winner should also be considered for purposes of a future disposal of the Property by the winner. The question in this regard is whether the market value of the Property (approximately R5.7 million) or the lot price paid (approximately R1658) will be regarded as the base cost for the winner.

According to the provisions of paragraph 20 of the Eighth Schedule, dealing with the base cost of an asset, primarily the expenditure actually incurred in respect of the cost of acquisition or creation of that asset is considered to be the base cost. In this case, it would therefore be the amount of R1658 paid for the lot by the winner. If the winner bought more than one lot, the base cost would arguably be the total amount of all the lots purchased. This may result in a significant capital gain in the future (even if the winner bought more than one lot) as the base cost would be insignificant.

Paragraph 38(1)(b) of the Eighth Schedule provides, however, that the base cost of an asset is equal to the market value of the asset for the person who acquired the asset (i.e. for the winner) if (1) a person disposed of an asset by means of a donation or (2) for a consideration not measurable in money or (3) to a person who is a connected person in relation to that person for a consideration that does not reflect an arm's length price. The first and third scenario should be considered in respect of the lottery transaction. It is submitted that the second scenario is not applicable as there is consideration that is measurable in money (the amount paid for the lot).

As it is required in terms of the first scenario of paragraph 38(1)(b) of the Eighth Schedule that the person (the owner) must dispose of the asset by means of a donation, it could be argued that there is no donation by the owner to the winner as the owner gives up the Property and receives the market value of the Property in return. Nothing is therefore donated from the owner's point of view in respect of the Property, and as such, the first scenario of paragraph $38(1)(b)$ of the Eighth Schedule is not applicable. 
Alternatively, in terms of the third scenario, only if the winner is a connected person to the owner, and if it is argued that the transaction did not take place at arm's length (if one takes into account the price of the lots compared to the value of the Property) then the base cost for the winner will be the market value of the Property when acquired. It is submitted that it will rarely be the case that the owner and the winner are related and therefore it seems that the base cost for the winner will be the lot price paid, which will result in significant capital gains tax consequences in the future should that person decide to dispose of the Property. At the time of disposal, other inclusions in the base cost may be relevant, such as expenditure actually incurred in respect of improvements to the Property (paragraph 20(1)(e) of the Eighth Schedule), but a detailed discussion thereof falls beyond the scope of this article.

\section{Other income tax considerations}

\section{Other income tax considerations for the owner}

Scheme of profit-making: South African courts have often drawn a distinction between the realisation of a capital asset and 'selling an asset in the course of carrying on a business or embarking on a scheme for profit' (Natal Estates Ltd $v$ Secretary for Inland Revenue 37 SATC 193:216, 'the Natal Estates case'). Amounts realised in terms of the former (i.e. when capital assets are realised) will be of a capital nature, with possible tax consequences in terms of the Eighth Schedule, while amounts realised in terms of a scheme of profit-making will be of an income nature, with a possible inclusion in 'gross income'.

It has been assumed above that the Property was disposed of by the owner in terms of the lottery as a capital asset (for example, as the owner's primary residence), and not as trading stock or as part of a scheme of profit-making. Accordingly, there should be no inclusion in the owner's 'gross income', as defined in Section 1 of the Income Tax Act, as 'gross income' excludes, with some exceptions known as the special inclusions, receipts or accruals of a capital nature. It should, however, briefly be considered whether the fact that the owner decides to dispose of the Property by way of a lottery, instead of by way of an ordinary sale, could result in the owner moving over from the realisation of a capital asset to a scheme of profit-making, which could result in an inclusion in the owner's 'gross income'.

In accordance with the terms of the lottery, the owner is only entitled to the market value of the Property, which is in line with an ordinary realisation of a capital asset at market value (assuming that transactions ordinarily take place in an open market at arm's length between a willing buyer and a willing seller). The owner did, however, acquire certain benefits in addition thereto, such as not being liable for estate agent commission. The question regarding whether the owner moved over to a scheme of profit-making is arguably even more relevant had the owner been entitled to the full proceeds from the sale of the lots, assuming that this amount could be substantially in excess of the market value of the Property.
There is no definition in the Income Tax Act of 'capital nature'. The most important factor to be considered when determining whether an amount is of a 'capital nature' is the taxpayer's intention when acquiring, holding and disposing of the asset (De Koker \& Williams 2001:§ 3.2). It is trite law that the intention of the owner with which an asset is held could change from holding the asset as a capital asset to the intention of profit-making when the asset is later disposed of. Even if it is assumed that the Property was initially acquired as a capital asset (for example, as the owner's private residence), the question is whether the owner's intention changed when embarking on the method of disposal of the Property by way of a lottery.

The realisation of a capital asset may be to the taxpayer's best advantage, 'however business like' (the Natal Estates case:214), and even if the realisation required the taxpayer to undertake certain 'operations' (which could arguably include lottery operations), the proceeds can be of a capital nature (the Natal Estates case:217). The mere fact that a taxpayer realises an asset to his or her best advantage (for example, by way of a lottery rather than an ordinary sale) does not necessarily mean that the taxpayer embarked on a scheme of profit-making (Elandsheuwel Farming (Edms) Bpk v Sekretaris van Binnelandse Inkomste 39 SATC 163:182, 'the Elandsheuwel case'). Despite this, 'there are, however, limits to what a taxpayer may do in order to realise to best advantage' (the Elandsheuwel case:182).

The question is whether such limits are transgressed when embarking on the method of realisation of the Property by way of a lottery. While the taxpayer's intention is the most important factor, such an intention must be aligned with the facts (De Koker \& Williams 2001:§ 3.12). This requires that a number of objective factors must also be considered when it is determined whether an amount is of a capital nature (De Koker \& Williams 2001:§ 3.12). Even though the lottery might, for example, be a once-off transaction for the owner, it is established law that:

it is not an essential requirement that a taxpayer be carrying on a trade or business in a particular type of asset in order for the proceeds derived from the sale of such an asset to be regarded as income. (De Koker \& Williams 2001:§ 3.15)

Therefore, the fact that the lottery only happens once does not automatically classify the proceeds as being of a capital nature. The question is rather whether there was an intention or a motive of profit-making (De Koker \& Williams 2001:§ 3.15).

In essence, a determination of whether an amount received or accrued is of an income or a capital nature will depend on the facts and circumstances of each case. More information regarding the owner and the owner's intention would be necessary to make such a determination. There is, however, a possibility that the Commissioner considers the proceeds from the lottery (or at least part thereof, i.e. the market value of the Property accruing to the owner as the terms of the lottery provide or had it been the full proceeds from the sale of the lots) to be of income nature in the hands of the owner. 
This will result in an inclusion in 'gross income', if the lottery operations are regarded as something more than just the realisation of a capital asset. This is arguably the case as setting up the lottery, administering the lottery, the draw of the winning lot, etc. could be regarded as something more than just disposing of a residence by way of an ordinary sale. The taxpayer would then have the onus of proof to show that the amount is of a capital nature (Section 102 of the Tax Administration Act 28 of 2011, 'Tax Administration Act'; CGT Guide 2015:12).

Should the result be that the proceeds from the lottery are included in the owner's 'gross income', it would also have to be considered whether any deductions can be made relating to such an inclusion, but a detailed discussion thereof falls beyond the scope of this article.

Savings and advantages for the owner: The owner embarks on the sale of the Property by way of a lottery as it results in a number of savings and advantages, namely that the owner is not liable for estate agent commission, that the owner does not have to make the Property available for viewings, that the owner does not have to consider any offers and that the sale will not be subject to conditions such as the buyer's mortgage bond approval (Tswanya 2015). It should be briefly considered whether any of these savings or advantages could result in any tax consequences in the hands of the owner. The saving of estate agent commission has an actual monetary value, while the values of the other advantages are not clear in monetary terms.

The mere fact that the owner is not liable for estate agent commission is similar to a situation where a seller sells a property privately, in other words, without the assistance of an estate agent. The fact that no estate agent commission is payable, assuming that the proceeds from the sale of a property are of a capital nature, already results in the realisation of a larger capital gain or a smaller capital loss. This is due to the fact that estate agent commission can be added to the base cost of the asset as an amount actually incurred as expenditure directly related to the disposal of an asset in terms of paragraph 20(1)(c)(i) of the Eighth Schedule. A lower base cost (if estate agent commission is not added) results in a larger capital gain or a smaller capital loss.

The question is whether such a saving of estate agent commission (which can be valued if a market related commission percentage is applied to the market value of the Property, but which cannot be converted into money) could be taxable in the hands of the owner, for example as an amount accrued to the owner (i.e. 'gross income'). In this regard, Commissioner for South African Revenue Service v Brummeria Renaissance (Pty) Ltd 69 SATC 205 ('the Brummeria case') should be briefly considered. In this case, the taxpayers granted life rights to occupiers in a retirement village in exchange for interest-free loans from the occupiers. Albeit the fact that the right to retain and use the loans interest-free could not be converted into money, the Supreme Court of Appeal held that 'the right to retain and use the borrowed funds without paying interest had a money value, and accordingly that the value of such right must be included in the companies' gross incomes for the years in which such rights accrued to the companies' (the Brummeria case:212).

It is, however, submitted that the Brummeria case is not applicable to the benefit of saving estate agent commission for a number of reasons. Firstly, in the Brummeria case, there was a right to retain and use the funds interest-free. In the case of the owner saving estate agent commission, there is no right being applicable; it is rather a consequence of the transaction being structured in a particular way. Further, in the Brummeria case, a quid pro quo was given by the taxpayers in exchange for the right to retain and use the funds interest-free (namely the life rights granted to the occupiers). Such a quid pro quo does not exist in the facts of the lottery as the owner gives nothing in return for the saving of estate agent commission. Also, it could be argued that the benefit of saving estate agent commission is regarded as a receipt or accrual of a capital nature, which means that there will not be an inclusion in 'gross income'.

The other benefits referred to, in addition to the saving of estate agent commission, could equally apply in an ordinary sale of property, where the buyer is unable or does not want to view the property, if the first offer is made in line with the price being advertised and if there are no conditions such as the buyer's mortgage bond approval. These benefits are not rights, cannot be converted into money and would further not have a monetary value as the valuation of these intangible benefits would not be possible or at best be highly speculative.

These advantages or benefits from the sale of the Property by way of a lottery accordingly do not give rise to any additional tax consequences in the hands of the owner, other than the consequential implications such as a larger capital gain or smaller capital loss as explained above.

\section{Other income tax considerations for the winner}

From the winner's point of view, it is clear that an amount is paid for the lot and that the Property, worth substantially more, is received in return as a prize. The question in this regard is whether anything could fall within the winner's 'gross income' relating to the prize. There is authority for proceeds of gambling, betting and lotteries being included in the 'gross income' of a taxpayer where the taxpayer conducts such activities regularly or systematically (De Koker \& Williams 2001:§ 3.26). It is, however, assumed that the winner of the Property does not partake in house lotteries regularly or systematically, but rather as a hobby or for entertainment and, as such, the value of the prize is not required to be included in the 'gross income' of the winner as it will be considered as being of a capital nature. See above for a discussion on the capital gains tax consequences for the winner. 


\section{Transfer duty consequences}

The main concerns regarding transfer duty in this specific transaction are the value on which transfer duty will be calculated and who will be liable for the transfer duty. The Transfer Duty Act 40 of 1949 ('the Transfer Duty Act') provides in Section 2 that transfer duty is levied on inter alia the value of any property acquired by any person by way of a transaction or in any other manner. It should be considered whether the winner acquires 'property' by way of a 'transaction' (each of these terms being defined in Section 1 of the Transfer Duty Act) by winning the Property and, if so, what the value of the Property is for purposes of transfer duty. In respect of the latter, the value could be, for example, the amount paid for the lot, the market value of the Property or the full proceeds realised from the sale of the lots.

It is clear from the definition of 'property' in Section 1 of the Transfer Duty Act that the winner acquires 'property' as the latter means land in the Republic and any fixtures thereon. Further, the Property is being acquired by way of a 'transaction' as this means an agreement whereby one party (being the owner) thereto agrees to otherwise dispose of property to another person (being the winner) (Section 1 of the Transfer Duty Act). Acquisition is not defined in the Transfer Duty Act, but its meaning has been settled by our courts as the acquisition of 'the right to acquire the ownership of property' (Commissioner for Inland Revenue $v$ Freddies Consolidated Mines Ltd 21 SATC 132:138). In accordance with the terms of the lottery, the winner becomes entitled to the Property once he or she accepts the prize. Transfer is then effected, after which the winner becomes the owner of the Property. By being the holder of the winning lot and by accepting the prize, the winner 'acquires' property as the winner acquires the right to acquire ownership of the property. It is, accordingly, clear that the requirements of the charging section for transfer duty are met.

Section 5 of the Transfer Duty Act regulates the value on which transfer duty is payable. In terms of Section 5(6) of the Transfer Duty Act, the transfer duty payable shall be calculated on the highest of the consideration payable by the person who acquires the property, the declared value of the property or the fair value of the property. Ordinarily, the consideration payable is used, and where no consideration is payable, the declared value is used (Section 5(1)(a) and $(b)$ of the Transfer Duty Act). However, Section 5(6) of the Transfer Duty Act then grants the Commissioner the power, if the Commissioner is of opinion that the consideration payable or the declared value is less than the fair value of the property, to use the fair value of the property.

These various values can further be analysed in terms of the lottery transaction as follows:

- The consideration payable by the winner who acquires the Property is the purchase price of the lot (R1658), being a minimal amount compared to the actual market value of the Property acquired.
- The 'declared value' is used where no consideration is payable and is defined in Section 1 of the Transfer Duty Act as the value of the property as declared in the declaration completed in terms of Section 14 of the Transfer Duty Act by the person who has acquired the property'. According to the SARS Transfer Duty Guide, 'declared value' means 'the 'fair market value of the property as at the date of acquisition' (South African Revenue Service: Transfer Duty Guide 2016:52). It is submitted that the declared value will, however, not be applicable as there is consideration payable by the person who acquires the Property, being the price of the lot paid by the winner.

- Lastly, the 'fair value' of the property means 'the fair market value of that property as at the date of acquisition thereof' (Section 1 of the Transfer Duty Act). 'Fair market value', which is not defined in the Transfer Duty Act, is defined in Section 1 of the Tax Administration Act as 'the price which could be obtained upon a sale of an asset between a willing buyer and a willing seller dealing at arm's length in an open market'. This would be the value of R5.7 million.

It is clear from the above that the fair value of the Property (R5.7 million) will be higher than the consideration payable by the winner (R1658).

Section 6 of the Transfer Duty Act, which requires that certain payments must be added to the consideration that is payable for the acquisition of property, should however be briefly considered. If one assumes that the price paid for the lot is the consideration payable for the acquisition of the Property, it has to be considered whether Section 6(1)(c) of the Transfer Duty Act would, for example, require that the surplus (the portion in excess of the market value of the Property which must be paid over to a charity after the deduction of certain costs) must be added to the consideration payable for purposes of the transfer duty calculation. In this regard, Section $6(1)(c)$ of the Transfer Duty Act requires that there must be added to the consideration payable:

any consideration which the person who has acquired property has paid or agreed to pay to any person whatsoever in respect of or in connection with the acquisition of the property, over and above the consideration payable to the person from whom the property was acquired.

It is submitted that neither of the provisions of Section 6(1) $(a)-(c)$ of the Transfer Duty Act are, however, applicable as each of these provisions requires that an amount must be paid 'by the person who acquired the property'. As the winner is not required to pay any amounts to, for example, the charity, these provisions are not applicable.

The fair value of the Property (R5.7 million) is thus the value on which transfer duty must be determined. The amount of transfer duty will be calculated in accordance with the rates set out in Section 2(1)(b) of the Transfer Duty Act. The rates are progressive and increase as the value or amount to which the rates are applied increases. Based on the rates applicable 
from 01 March 2017 and on the market value of the Property of R5.7 million, transfer duty would amount to R460 000 .

Section 2 of the Transfer Duty Act clearly places the liability for transfer duty on the winner as he or she is the person acquiring the Property. In this regard, it is noted from the terms of the lottery that 'all transfer costs and costs related to the transfer of the property will be covered by the Owner via the Lottery takings'. It is assumed that transfer duty will be included under 'all transfer costs and costs related to the transfer of the property'. Accordingly, it seems that these costs are paid from the surplus, that is, the excess of the proceeds realised from the sale of the lots after the owner has received the market value, which is eventually, after the costs have been paid, paid over to a charity.

If the winner's debt towards SARS in respect of transfer duty is paid from the surplus, this could amount to a 'donation' (as defined in Section 55 of the Income Tax Act) to the winner which could be subject to donations tax at 20\% (Section 54 read with Section 64 of the Income Tax Act). A 'donation' is defined in Section 54 of the Income Tax Act as 'any gratuitous disposal of property'. Without concluding on whether there would be a 'donation' in this regard, this possible tax consideration serves as proof that the selected method of the disposal of the Property by way of the lottery may have unintended or unplanned tax consequences for the parties involved.

It is submitted that the Brummeria case would, however, not be applicable to this benefit obtained by the winner (i.e. the benefit of not having to pay transfer duty for which the winner is liable, which benefit can be valued but which cannot be converted into money) for the same reasons outlined above in the discussion of the owner's savings or advantages by disposing of the Property by way of a lottery. Even though the winner has a right to the benefit of not having to pay transfer duty in accordance with the terms of the lottery, there is no quid pro quo given by the winner in exchange for the right.

\section{Donations tax considerations and consequences}

A possible donations tax consequence has already been highlighted above in respect of the transfer duty being paid on behalf of the winner from the surplus. Two further possible donations could exist. Firstly, due to the fact that the price paid for the lot by the winner is much lower than the value of the Property received in return by the winner, the question arises as to whether the transaction (disposing of the Property through a lottery) amounts to a 'donation'. Secondly, the donation to a charity should be considered in respect of the surplus (i.e. the difference between the market value of the Property to which the owner is entitled and the total value of the lots sold, which will be donated to a charity, after promotional and other costs are deducted).

Section 55 of the Income Tax Act defines a 'donation' as 'any gratuitous disposal of property including any gratuitous waiver or renunciation of a right'. Therefore, the meaning of 'gratuitous' is important to define a 'donation'. De Koker and Williams (2001: 23.3$)$ state that if the disposed item is 'given for nothing, without charge, free', then the disposition is seen as gratuitous. It is noted above that there is no donation made by the owner as the owner disposes of the Property but receives the market value of the Property in return. Nothing is thus donated from the owner's point of view in respect of the Property as there is no 'gratuitous disposal'. Therefore, although from the winner's point of view it seems like a donation exists, as the Property worth substantially more than the lot price is received in return, no donation is made by the owner and the lottery transaction as a whole is not a 'donation' by the owner to the winner.

The surplus given to a charity is clearly a 'donation' in terms of Section 55 of the Income Tax Act. It is assumed that the charity to whom the donation is made is an approved public benefit organisation, which means that the donation will be exempt from donations tax in terms of Section 56(1) (h) of the Income Tax Act and no donations tax will be payable. As mentioned above, it is not clear from the available terms and conditions who the donor of this donation to the charity is. It is, however, assumed that the donor is not the owner as the owner is only entitled to the market value of the property. It may be noted that donations tax is only applicable in terms of Section 54 of the Income Tax Act if the donation is made by a 'resident' as defined in Section 1. As such, considering the exemption from donations tax in terms of Section 56(1)(h) may be irrelevant if the donor is not a 'resident'.

\section{Conclusion}

The research objective of this article is to explore some of the most pertinent South African tax consequences of the disposal and acquisition of a residential property by way of a lottery, as no such research currently exists, and no specific guidance is available in this regard to determine the South African tax consequences of such a transaction. It has been set out above that a transaction as such results in a number of actual tax consequences for the owner and the winner, while a number of uncertainties were also identified (referred to above as 'considerations'). It was determined that the lottery transaction can create potential tax risks or can result in unintended tax consequences, relating to inter alia income tax (including capital gains tax), transfer duty and donations tax for the owner and the winner.

Should a person consider disposing of property by way of a lottery (i.e. from the owner's point of view), it should be carefully considered whether the tax consequences that arise as a result of the disposal being structured as a lottery, in addition to the tax consequences had the disposal being structured as, for example, an ordinary sale, still make the transaction as attractive and beneficial as it appears to be. The benefits for the owner by disposing of the property by way of a lottery may be outweighed by the possible additional tax liability (should the transaction, for example, 
be regarded as a scheme of profit-making, resulting in an inclusion in the owner's 'gross income') and other unintended tax consequences.

Should a person buy a lot and be the winner of the property (i.e. from the winner's point of view), the transaction may result in immediate and significant tax consequences (for example, should paragraph 60 of the Eighth Schedule be applicable). If the winner is not able to settle a possible tax liability as such, he or she may be necessitated to sell the property which, as a disposal of an asset is also identified as a significant tax consequence.

As mentioned above, the scope of this article is limited, and a number of assumptions were made. The tax consequences and considerations that are explored above could not be addressed comprehensively and in depth in this article. In this regard, areas for further research are identified, which include:

- Determine if the lottery or participation therein is illegal or unlawful in South Africa and the tax consequences, if any, should the lottery or participation therein be illegal or unlawful in South Africa.

- Determine the time of disposal for the owner in terms of paragraph 13 of the Eighth Schedule.

- Consider the tax consequences if the amount in excess of the market value of the Property also accrues to the owner.

- Determine the implications, if any, of paragraph 20(1)(c) (vii), read together with paragraph 22, of the Eighth Schedule in terms of which a portion of donations tax payable is included in the base cost of an asset in the case of a disposal of an asset by a person (the owner) by way of a donation. This becomes relevant should the 'disposal' by the owner be classified as a donation in terms of paragraph 11 of the Eighth Schedule.

- Should the result be that the proceeds from the lottery are included in the owner's 'gross income', determine whether any deductions can be made relating to such an inclusion.

- Consider the exchange control consequences of the transaction as it was administered in Austria.

Should residential property lottery transactions occur more frequently in South Africa in future, it is recommended that the SARS issues clear guidance on the tax treatment from the perspective of the owner and the winner of such a transaction to ensure that any uncertainties are dealt with correctly.

\section{Acknowledgements Competing interests}

The authors declare that they have no financial or personal relationships that may have inappropriately influenced them in writing this article.

\section{Authors' contributions}

Both, S.d.L. and D.v.W. the authors have contributed equally to the writing of this article.

\section{References}

Brown, R.B., 2006, Doing your dissertation in business and management: The reality of research and writing, Sage, London.

Commissioner for Inland Revenue v Freddies Consolidated Mines Ltd 195721 SATC 132.

Commissioner for South African Revenue Service v Brummeria Renaissance (Pty) Ltd 200769 SATC 205.

De Koker, A.P. \& Williams, R.C., 2001, Silke on South African Income Tax, electronic edition updated April 2017, LexisNexis, viewed 03 October 2017, from http:// www.mylexisnexis.co.za.ez.sun.ac.za/Index.aspx

Elandsheuwel Farming (Edms) Bpk v Sekretaris van Binnelandse Inkomste 197839 SATC 163

Geldenhuys v Commissioner for Inland Revenue 194714 SATC 419.

Hutchinson, T. \& Duncan, N., 2012, 'Defining and describing what we do: Doctrinal legal research', Deakin Law Review 17(1), 83-119. https://doi.org/10.21153/ dlr2012vol17no1art70

Kok, L., 2009, 2010 villa raffle: Scam or scintillating opportunity?, viewed 15 November 2016, from http://www.moneyweb.co.za/archive/2010-villa-raffle-scam-orscintillating-opportun-2/

Lategan WH v Commissioner for Inland Revenue 19262 SATC 16.

Natal Estates Ltd v Secretary for Inland Revenue 197537 SATC 193

Ostler, L., 2013, Taxation of gambling winnings - Changes afoot, viewed 12 January 2017, from http://www.schoemanlaw.co.za

Qukula, Q., 2015, Austrian lottery raffles SA property and other assets with good odds viewed 14 December 2016, from http://www.capetalk.co.za/articles/3694/ austrian-lottery-raffles-property-and-other-assets-with-good-odds

Republic of South Africa, 1949, Transfer Duty Act 40 of 1949, Government Printer, Pretoria.

Republic of South Africa, 1962, Income Tax Act 58 of 1962, Government Printer Pretoria.

Republic of South Africa, 1991, Value-Added Tax Act 89 of 1991, Government Printer, Pretoria.

Republic of South Africa, 2011, Tax Administration Act 28 of 2011, Government Printer, Pretoria.

Republic of South Africa, South African Revenue Service, 2015, Comprehensive guide to capital gains tax (issue 5), SARS, Pretoria.

Republic of South Africa, South African Revenue Service, 2016, Transfer duty guide, SARS, Pretoria.

Singh, K., 2007, Quantitative social research methods, Sage, London.

Tswanya, Y., 2015, Upmarket home up for grabs in lottery, viewed 31 October 2016, from http://www.iol.co.za/news/south-africa/western-cape/upmarket-home-upfor-grabs-in-lottery-1892419

United Kingdom Law Society, 2011, House competitions, viewed 28 June 2017, from https://www.lawsociety.org.uk/support-services/advice/practice-notes/housecompetitions/

Val de Vie, viewed 12 December 2016, from http://www.valdevie.co.za/aboutus/ourhistory.html 